\title{
RESEARCH
}

Open Access

\section{Positive association between forest management, environmental change, and forest bird abundance}

Ernst Detlef Schulze ${ }^{1 *}$ (D), Dylan Craven ${ }^{2}$, Andrew M. Durso ${ }^{1}$, Jiri Reif ${ }^{3}$, Marcus Guderle ${ }^{1}$, Franz Kroiher ${ }^{4}$, Petra Hennig ${ }^{4}$, Anne Weiserbs ${ }^{5}$, Peter Schall ${ }^{6}$, Christian Ammer ${ }^{6}$ and Nico Eisenhauer ${ }^{7}$

\begin{abstract}
Background: The global decrease in wildlife populations, especially birds, is mainly due to land use change and increasing intensity of land use (Parmesan and Yohe 2003). However, impacts of management tools to mitigate biodiversity loss at regional and global scales are less apparent in forest regions that have a constant forest area, and which did not suffer from habitat degradation, and where forests are sustainably managed, such as in Central Europe or the northeastern USA. A biodiversity assessment for Germany suggested, for example, that bird populations were constant (Bundesamt für Naturschutz 2015).
\end{abstract}

Results: This study shows that changes in the environment and in forest management over the past 45 years have had a significant, positive effect on the abundance of non-migratory forest bird species in Central Europe. Economy (timber prices and GDP), forest management (timber harvest and mixed forest area), and environmental factors (atmospheric $\mathrm{CO}_{2}$ concentration and nitrogen deposition) were investigated together with changes in abundances of migratory and non-migratory forest birds using partial least squares path modeling. Climate change, resulting in longer seasons and milder winters, and forest management, promoting tree diversity, were significantly positively related to the abundance of non-migratory forest birds and explained $92 \%$ of the variation in their abundance in Europe. Regionally-migrating forest birds had stable populations with large variation, while birds migrating across continents declined in recent decades, suggesting significant, contrasting changes in bird populations in Europe. In northeastern North America we also found evidence that non-migratory forests have experienced long-term increases in abundance, and this increase was related to management. The increase of populations of nonmigratory forest birds in Europe and North America is associated with an increase in structural diversity and disturbances at the landscape level.

Conclusions: Our results suggest that reports about bird decline in forests should separate between migratory and non-migratory bird species. Efforts to mitigate the general decline in bird abundance should focus on land-use systems other than forests and support sustainable forest management independent of economic conditions.

Keywords: Climate change, Birds, Biodiversity, Timber harvest, Economy, Forest management

\footnotetext{
* Correspondence: dschulze@bgc-jena.mpg.de

${ }^{1}$ Max Planck Institute for Biogeochemistry, PO Box 100164, 07701 Jena,

Germany

Full list of author information is available at the end of the article
} 


\section{Introduction}

Changes in biodiversity have received increasing scientific and political attention (Parmesan and Yohe 2003; Cardinale et al. 2012) because of species losses and the spread of pests and diseases (Armstrong 2017). To reduce further biodiversity loss, setting aside large forest areas has been suggested as one major management tool at regional and global scales (BMU 2007; Pollock et al. 2017). While proximate causes for the decline of specific species, such as land-use change (Wade et al. 2013), have been identified, the impacts of socio-economic factors, global climate change, and forest management on biodiversity in general remain unclear.

Here we show that changes in the environment and in forest management are positively related to the abundance of native, non-migratory bird species that are forest specialists in Central Europe. In order to test if our observations are only of regional importance, we compared the European situation with deciduous forests in North America. For Europe, we assembled long-term records of economic factors (timber prices and GDP) and associated changes in forest management intensity (timber harvest, fraction of mixed forest area), together with changes in key environmental factors, mainly atmospheric $\mathrm{CO}_{2}$ concentration and nitrogen deposition, as proxies for climate change (Vicca et al. 2012; Drobyshev et al. 2014; Fu et al. 2015; Park et al. 2016). Because birds are used as a key indicator of ecosystem health (Bundesamt für Naturschutz 2015; European Commission 2015; San-Miguel-Ayanz et al. 2016), we associated these parameters with the abundance of multiple groups of forest specialist bird species by using partial least squares path modeling.

Our results provide evidence that both climate change and forest management were positively associated with the abundance of non-migratory forest birds. Our findings are in contrast to the general decline of birds in areas dominated by other land uses, e.g. farmlands, in Europe (Donald et al. 2001; Inger et al. 2015; Reif and Hanzelka 2016; European Bird Census Council 2018), but confirm the observed population trends of woodland bird species in Europe (Gregory et al. 2007; Ram et al. 2017). In temperate regions with stable amounts of forested land cover and sustainable forest management, non-migratory forest bird populations are stable or even increasing, with evidence that both migratory and resident species may benefit from moderate-intensity forest management or disturbance (King and DeGraaf 2000; Bakermans and Rodewald 2009; Sheehan et al. 2014). Our results suggest that the overall decline in bird abundance and diversity could be mitigated by focusing on non-forest ecosystems.

\section{Materials and methods}

\section{Environmental and economic variables}

To quantify temporal changes in environmental and economic variables in Central Europe, we obtained country-level data. We focused on Germany because a wide array of relevant data has been collected in a consistent manner for longer time periods than other countries in Central Europe. This study uses standing timber volumes in Germany (Thünen-Institut 2012), changes in atmospheric $\mathrm{CO}_{2}$ concentration (Le Quéré et al. 2016) and nitrogen deposition over Germany (Thünen-Institut 2016), wood prices in Germany (https://www.holzmarktinfo.de/; $100 \%$ wood price is the value in 2010), gross domestic product (GDP) for Germany as corrected for inflation (Organisation for Economic Cooperation and Development 2008), and the US National Audubon Society Christmas Bird Count data (National Audubon Society 2018) from the US states of Connecticut, Maine, Massachusetts, Michigan, Minnesota, New Hampshire, New York, Pennsylvania, Rhode Island, Vermont, West Virginia, and Wisconsin.

\section{Bird abundance data}

Trends in bird species abundance come from the European Bird Census Council (2018) for central Europe, which includes Austria, Belgium, Czech Republic, Germany, and Slovakia. We focus on bird species that have breeding populations in these countries (Table 1). This limits the selection of species to common birds irrespective of their nesting requirements. The Phasianidae (grouse \& other upland gamebirds) are not part of this observation scheme (except for Tetrastes bonasia), which was not included because of its absence from most lowland forests in central Europe. Populations of existing Phasianidae in Central Europe are also distorted due to artificial introductions. The Strigidae (owls) are also not part of this observation scheme, even though they contain true forest specialists. We are aware that grouse and some forest owls are in decline due to many causes, including human disturbance.

The common bird monitoring time series was extended to the past decades based on observations of Blue Tid, Parus caeruleus, and Great Tid, Parus major, since 1926 and of Eurasian Nuthatch, Sitta europaea, since 1957 (Berndt and Winkel 1979; Winkel 2002). A linear regression through the data of these species reaches $56 \%$ abundance in 1970, and a linear regression through the common bird monitoring data predicts 55\% abundance in 1970. The slopes of change after 1970 were slightly lower, but not significantly different for Parus spp. compared to the other species (average slope for Parus spp.: 1.72 change in abundance per year (s.d. 0.32) as compared to 2.30 change in abundance (s.d. 0.86)).

\section{Data analysis}

We used partial least squares modeling with the 'PLS-PM' package (Sanchez et al. 2013) in R v. 3.4. 4 (R Core Team 2018), which is non-parametric and does not 
Table 1 Forest bird species of central Europe, and of the northeastern USA (National Audubon Society 2018), and a list of species that are used as indicator in Germany (Bundesamt für Naturschutz 2015). All available data and species were used

\begin{tabular}{|c|c|c|c|c|c|}
\hline \multicolumn{2}{|c|}{ Forest specialist bird species of central Europe } & \multicolumn{2}{|c|}{ Regionally-migrating bird species of central Europe } & \multicolumn{2}{|c|}{$\begin{array}{l}\text { Continentally-migrating forest birds of } \\
\text { central Europe }\end{array}$} \\
\hline $\begin{array}{l}\text { Certhia } \\
\text { brachydactyla }\end{array}$ & Short-toed Treecreeper & Carduelis spinus & Eurasian Siskin & Anthus trivialis & Tree Pipit \\
\hline Dendrocopos major & $\begin{array}{l}\text { Great Spotted } \\
\text { Woodpecker }\end{array}$ & $\begin{array}{l}\text { Coccottraustes } \\
\text { coccothraustes }\end{array}$ & Hawfinch & Ficedula hypoleuca & Pied Flycatcher \\
\hline $\begin{array}{l}\text { Dendrocopos } \\
\text { martius }\end{array}$ & Black Woodpecker & Columba oenas & Stock Dove & $\begin{array}{l}\text { Phoenicurus } \\
\text { phoenicurus }\end{array}$ & $\begin{array}{l}\text { Common } \\
\text { Redstart }\end{array}$ \\
\hline Dendrocopos medius & $\begin{array}{l}\text { Middle Spotted } \\
\text { Woodpecker }\end{array}$ & Parus ater & Coal Tit & Phylloscopus sibilatrix & Wood Warbler \\
\hline Dendrocopos minor & $\begin{array}{l}\text { Lesser Spotted } \\
\text { Woodpecker }\end{array}$ & Parus cristatus & Crested Tit & & \\
\hline Garrulus glandarius & Eurasian Jay & Phylloscopus collybita & Common Chiffchaff & & \\
\hline Parus caeruleus $^{\mathrm{a}}$ & Eurasian Blue Tit & Regulus ignicapilla & Firecrest & & \\
\hline Parus major ${ }^{a}$ & Great Tit & Regulus regulus & Goldcrest & & \\
\hline Parus palustris & Marsh Tit & Turdus viscivorus & Mistle Thrush & & \\
\hline Picus canus & Grey-headed Woodpecker & & & & \\
\hline Pyrrhula pyrrhula & Bullfinch & & & & \\
\hline Sitta europea & Eurasian Nuthatch & & & & \\
\hline
\end{tabular}

Forest specialist bird species of the northeastern USA

\begin{tabular}{|c|c|c|c|}
\hline Certhia americana & Brown Creeper & Aquila pomerina & Lesser Spotted Eagle \\
\hline Cyanocitta cristata & Blue Jay & Ciconia nigra & Black Stork \\
\hline Dryobates pubescens & Downy Woodpecker & Dryocopus martius & Black Woodpecker \\
\hline Dryocopus pileatus & Pileated Woodpecker & Dryocopus medius & $\begin{array}{l}\text { Middle Spotted } \\
\text { Woodpecker }\end{array}$ \\
\hline $\begin{array}{l}\text { Leuconotopicus } \\
\text { villosus }\end{array}$ & Hairy Woodpecker & Dryocopus minor & $\begin{array}{l}\text { Lesser Spotted } \\
\text { Woodpecker }\end{array}$ \\
\hline Poecile atricapillatus & Black-capped Chickadee & Parus ater & Coal Tit \\
\hline Regulus atrapa & Golden-crowned Kinglet & Parus montanus & Willow Tit \\
\hline Sitta canadensis & Red-breasted Nuthatch & Parus palustris & Marsh Tit \\
\hline Sitta carolinensis & White-breasted Nuthatch & Phylloscopus sibilatrix & Wood Warbler \\
\hline \multirow[t]{2}{*}{ Zonotrichia albicollis } & White-throated Sparrow & Picus canus & Grey-headed Woodpecker \\
\hline & & Sitta europaea & Eurasian Nuthatch \\
\hline
\end{tabular}

andicates regionally migrating species with long-term observations (Berndt and Winkel 1979; Winkel 2002)

have any distributional assumptions, to explain the effects of economic and environmental drivers and of forest management on biodiversity, here defined by the abundance of central European forest specialist bird species from 1980 to 2014. As these variables are theoretical concepts, i.e. not measured directly, we created latent variables for each. We used the wood price index and gross domestic product (GDP) as indicator variables for 'Economy', $\mathrm{CO}_{2}$ concentrations and $\mathrm{N}$ deposition (standardized using 1990 as baseline) as indicator variables for 'Environment', cuttings per area per year and the percent of mixed forest area as indicator variables for 'Forest management', and the abundances of 12 forest specialist bird species as indicator variables for 'Bird Abundance'. We fit the PLS-PM using 1000 bootstrap samples to estimate model parameters. To evaluate the fitted PLS-PM, we first assessed the reflective measurement model using Cronbach's alpha and the first eigenvalue to ensure that the selected indicator variables agree with their corresponding latent variable. The latent variables were unidimensional, meaning that the indicator variables are strongly associated with their latent variable, as indicated by Cronbach's alpha and the first eigen-values for each latent variable. Cronbach's alpha was greater than 0.7 for all latent variables except 'Economy' (Cronbach's alpha $=0.57$ ) and all first eigen-values 
were $\geq 1$. We then assessed the structural part of the PLS-PM using goodness-of-fit for the entire model and $R^{2}$ for endogenous variables. Goodness-of-fit, which is an index of prediction of the entire model, was 0.72 , and the mean bootstrapped $R^{2}$ values of the latent variables ranged from 0.81 to 0.92 . Together, this information indicates that the PLS-PM fit the data well and has reasonable predictive power. In order to handle the multiple arrays of parameters, latent variables were defined as Economy, Environment, and Forest Management, which are quantified by indicator variables containing the actual time series data. After running the model for non-migratory forest birds, we fit the first model again, but then added separate latent variable for the two other groups of birds. We analyzed temporal trends in bird abundance using linear regression analysis.

\section{Results}

Long-term trends in economic and environmental factors

Economic activity in Europe, e.g. Germany, has shown considerable variability since 1936 (Fig. 1). While GDP has increased steadily over the past several decades, timber prices have experienced major oscillations, with a maximum in 2015, high levels in the 1970s and 1980s, and a decline in the 1990s. Wood harvest was not correlated with timber price nor technology but rather peaked during World War II as well as periodically thereafter following extreme wind throw events (1990, 1999, 2007; Fig. 1). As a consequence of changing silvicultural management practices, the proportion of uneven-aged mixed forest stands has increased over the past few decades by almost $18 \%$, presently making up two thirds of all forests in Germany (Thünen-Institut 2012; Umweltbundesamt 2015).

In parallel, between 2002 and 2012, the amount of protected forest area in Germany increased from $1 \%$ to $4 \%$, but these protected areas are spatially highly aggregated (Thünen-Institut 2012; T1.3.1, T1.7.5 and T1.7.2) and their total area is an order of magnitude smaller than that of all mixed-species forest in Germany. Thus, the effect of taking forests out of management on bird populations is probably minor at large spatial scales, but its implications require further observation. In addition, average stand volume has increased by $10 \%$ between the first (1987) and the last (2012) German national forest inventory (www.Bundeswaldinventur.de/en), which could affect bird diversity (King and DeGraaf 2000).

Over this same time period, environmental conditions in Central Europe have also changed markedly, largely due to continued greenhouse gas emissions and a recent decrease in pollution, e.g. $\mathrm{N}$ deposition (Fig. 1). Atmospheric $\mathrm{CO}_{2}$ concentration was chosen as an indicator for a range of associated environmental factors, such as

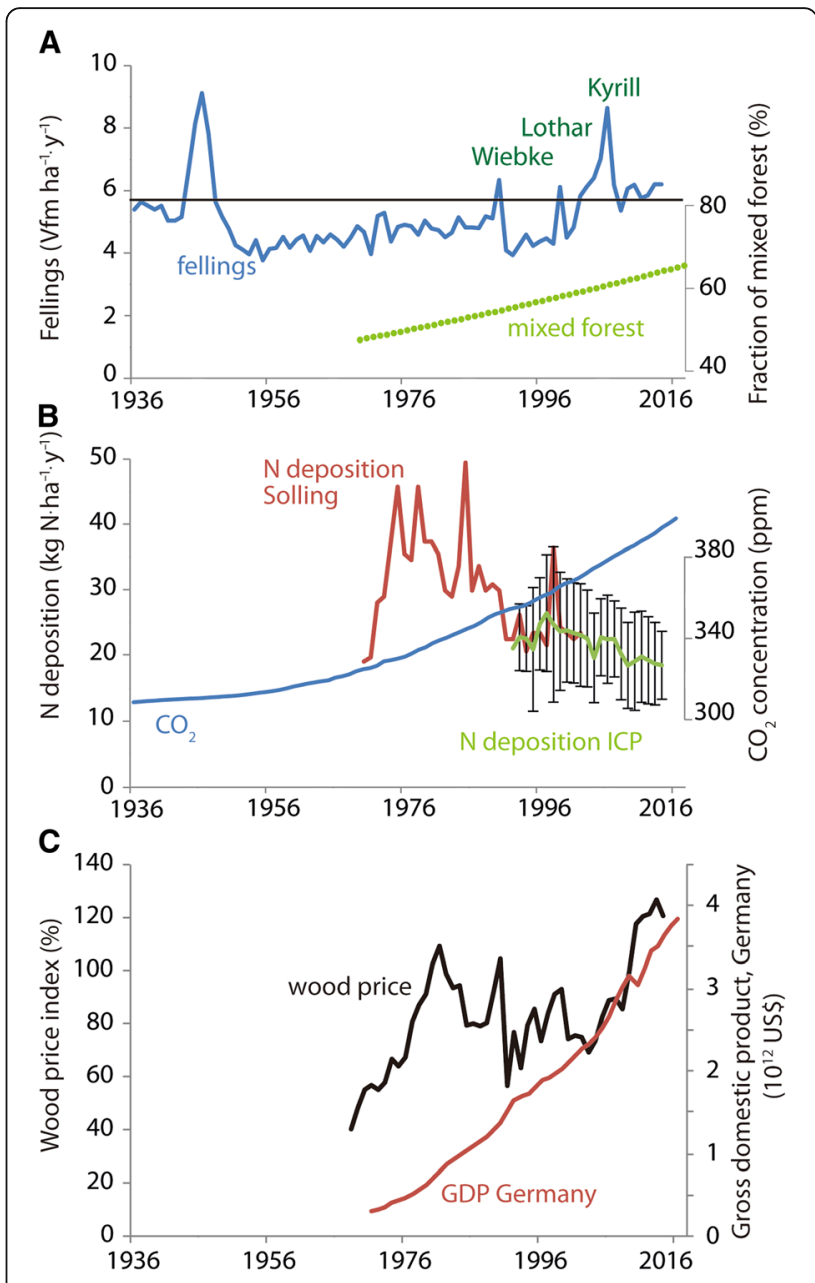

Fig. 1 Temporal trends in economic, forest management, and key environmental factors in Germany. Time series of (a) wood felling (removals) in forests (names of major storms causing wind throw events in dark green; Steinsiek 2016; Weimar 2016) and fraction of mixed forest in Germany (Thünen-Institut 2012), b changes in atmospheric $\mathrm{CO}_{2}$ concentration (Le Quéré et al. 2016) and nitrogen deposition (Brumme and Khanna 2009; Thünen-Institut 2016) at the Solling research area near Göttingen, Germany, and (c) wood prices (https://www.holzmarktinfo.de/; 100\% wood price is the value in 2010) and Gross Domestic Product (GDP), corrected for inflation (Organisation for Economic Cooperation and Development 2008)

winter temperature, length of the growing season, and rainfall distribution (Keenan et al. 2014; Fu et al. 2015). The rate of $\mathrm{N}$-deposition in forests has steadily decreased since 1970. This trend represents conditions across Central Europe (European Environment Agency 1998), and may even be similar to those in northeastern USA (Du et al. 2014).

\section{Trends in European forest bird populations}

In an attempt to protect the European environment against biodiversity loss, the EU Natura 2000 program (European Commission 2015) classified forests into 
priority types based on phyto-sociological criteria (Braun-Blanquet 1964). As plants appear to be more robust to environmental changes than animals (Voigt et al. 2007; Hines et al. 2015), birds were chosen as a more sensitive indicator for identifying the effects of land use (Bundesamt für Naturschutz 2015; European Commission 2015; San-Miguel-Ayanz et al. 2016). Since the extirpation of large predatory mammals, e.g. wolves and bears, birds are among the top predators in Central European ecosystems, especially of invertebrates. Thus, birds should respond rapidly to changes in their environment that may affect habitat and food availability (Bundesamt für Naturschutz 2015; Hallmann et al. 2017).

Since 1970, the abundance of 11 monitored forest bird species (Bundesamt für Naturschutz 2015, see methods for the species list) has remained constant in Germany (Fig. 2a). This finding is further supported by observations of 29 species by Natura 2000 (European Commission 2015), and of 34 species by the European Tree Atlas (San-Miguel-Ayanz et al. 2016). Here we assess temporal changes in the abundances of bird species specialized to live in forests (forest specialists) in central Europe that are part of the PAN European Common Bird Monitoring Scheme (PECBMS; European Bird Census Council 2018; see methods). Bird species that breed in European forests, but migrate into Africa after the breeding season, are generally in decline. This is in contrast to bird species that migrate only regionally within Europe. These species show on average a constant abundance over time, albeit with large variations (Fig. 2c). In
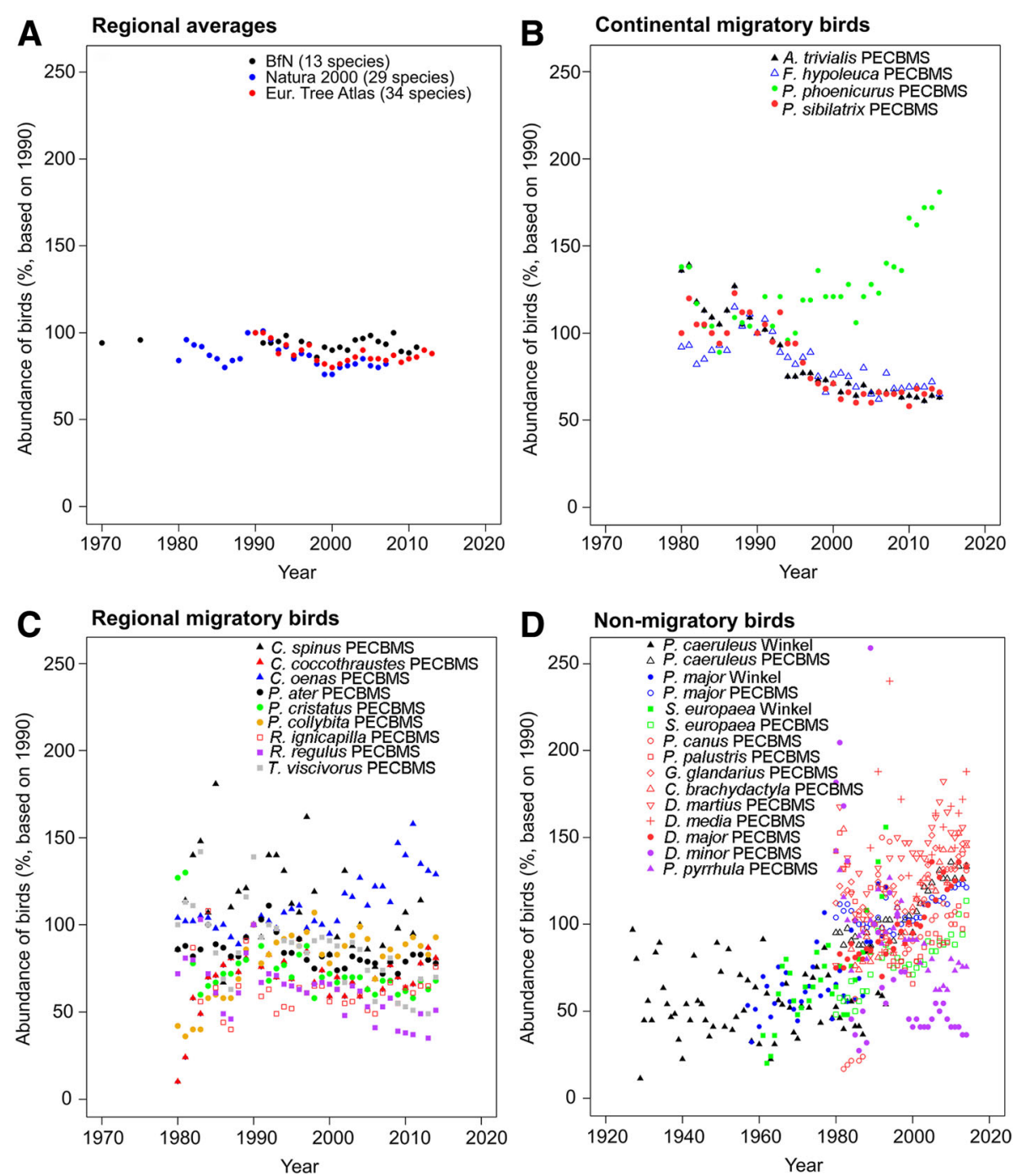

Fig. 2 Decadal trends in populations of forest bird species over Europe. a: Averages of selected groups of bird species across Germany (Bundesamt für Naturschutz 2015) and Europe (European Commission 2015; San-Miguel-Ayanz et al. 2016; Schulze 2017); b: continentallymigratory forest birds; $\mathbf{c}$ : regionally-migratory forest birds; and $\mathbf{d}$ : non-migratory forest birds following PECBMS European bird observations (Schulze 2017; European Bird Census Council 2018). For species list and key, see methods Table 1 


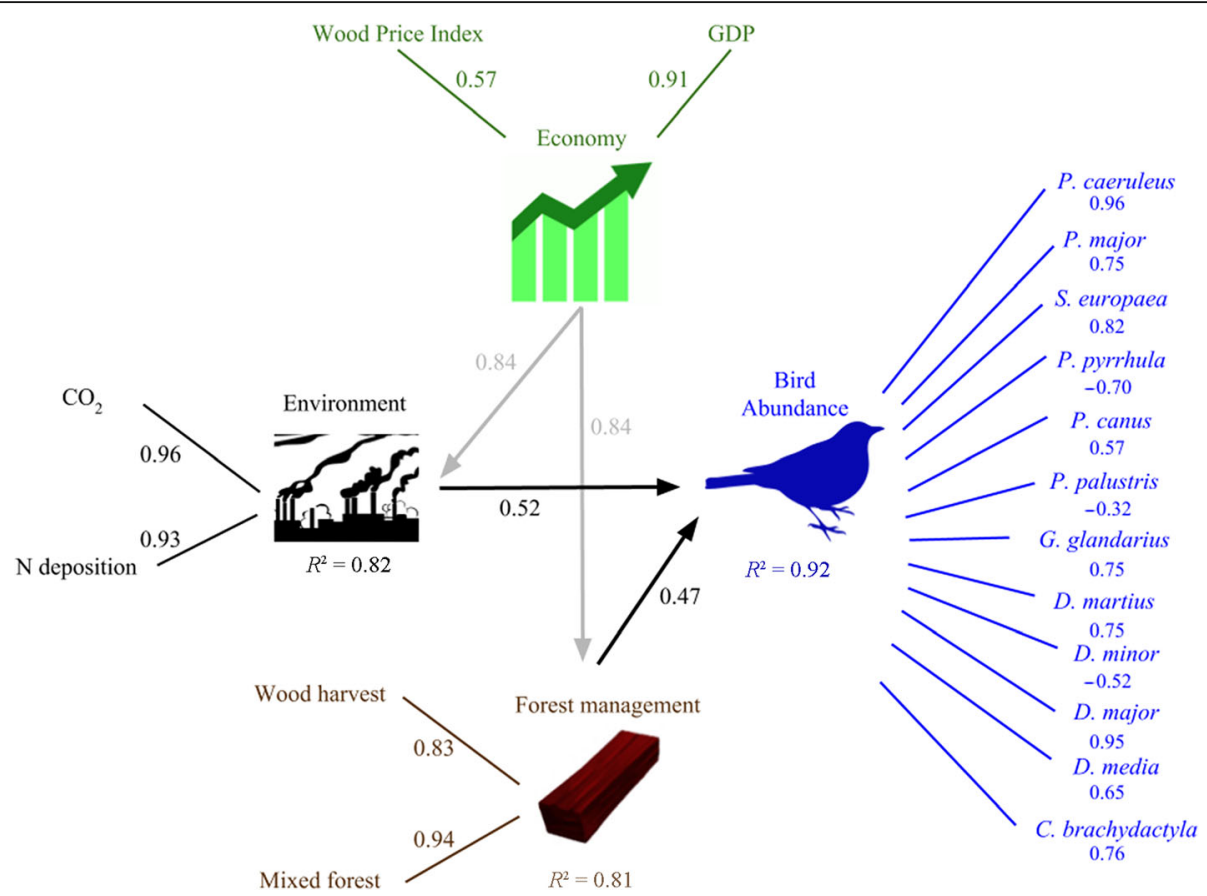

Fig. 3 Relationships between economic, environmental, and forest management and effects on abundance of non-migratory forest birds in Central Europe from 1980 to 2014. Variables are grouped into the latent variables Economy, Environment, Forest Management, and Bird Abundance. The direction and strength of relationships between the original variables and the respective latent variables are indicated by a solid line and standardized path coefficient. Significant path coefficients are represented as black arrows. Grey arrows indicate non-significant path coefficients. For bird genera see methods

contrast, non-migratory forest specialists show a general increase in abundance since about 1970 (Reif et al. 2007; Reif et al. 2008; Fig. 2d).

\section{Path model of relationship between economy,} environment, forest management, and bird populations In an attempt to explain these diverse observations, we focus in the following on non-migratory forest bird species (Gregory et al. 2007; Vickery et al. 2014; Bairlein 2016). We used partial least squares modeling (see Methods) to explore the direct and indirect relationships among economic and environmental drivers, forest management, and biodiversity, here defined by the abundance of central European forest specialist bird species.

We found strong, direct impacts of changing environmental conditions and forest management on forest specialist birds in Central Europe over three decades (Fig. 3).

Changing environmental conditions and forest management practices explained $92 \%$ of the variation in forest bird populations. These impacts were similar in magnitude (standardized path coefficient of environment on bird abundance was 0.52; standardized path coefficient of forest management on bird abundance was 0.47 ). Our model provides evidence that the abundance of forest specialist birds increased in response to these factors (Fig. 3). We emphasize that the region under study is a managed landscape with a long history of forest management (Zvelebil 2001) and a relatively constant forest area during the study period (Thünen-Institut 2012).

The response of regionally and continentally migrating forest bird species is different to that observed for forest specialist bird species. We found a negative response to environmental change, and to a lesser extent, a negative response to forest management. However, this model does not account for changes in winter habitats, and it does not show potential interactions between resident and migratory species (Fig. 4).

\section{Trends in forest bird populations in the northeastern USA} This counter-intuitive observation of increasing abundance in non-migratory forest birds raises the question of whether observations from Central Europe can be generalized across other regions or continents. Both Europe and the northeastern USA experienced similar levels of deforestation in the 18th and nineteenth century (Houghton et al. 1999; Küster 2003), are ecologically similar with respect to the main genera of forest tree species (Schulze et al. 1996), and share a similar history of pollution ( $\mathrm{Du}$ et al. 2014). Long-term data on forest bird abundance in northeastern (NE) USA provide an opportunity for such a comparison. Using long-term data (1950-2017) from the National Audubon Society 


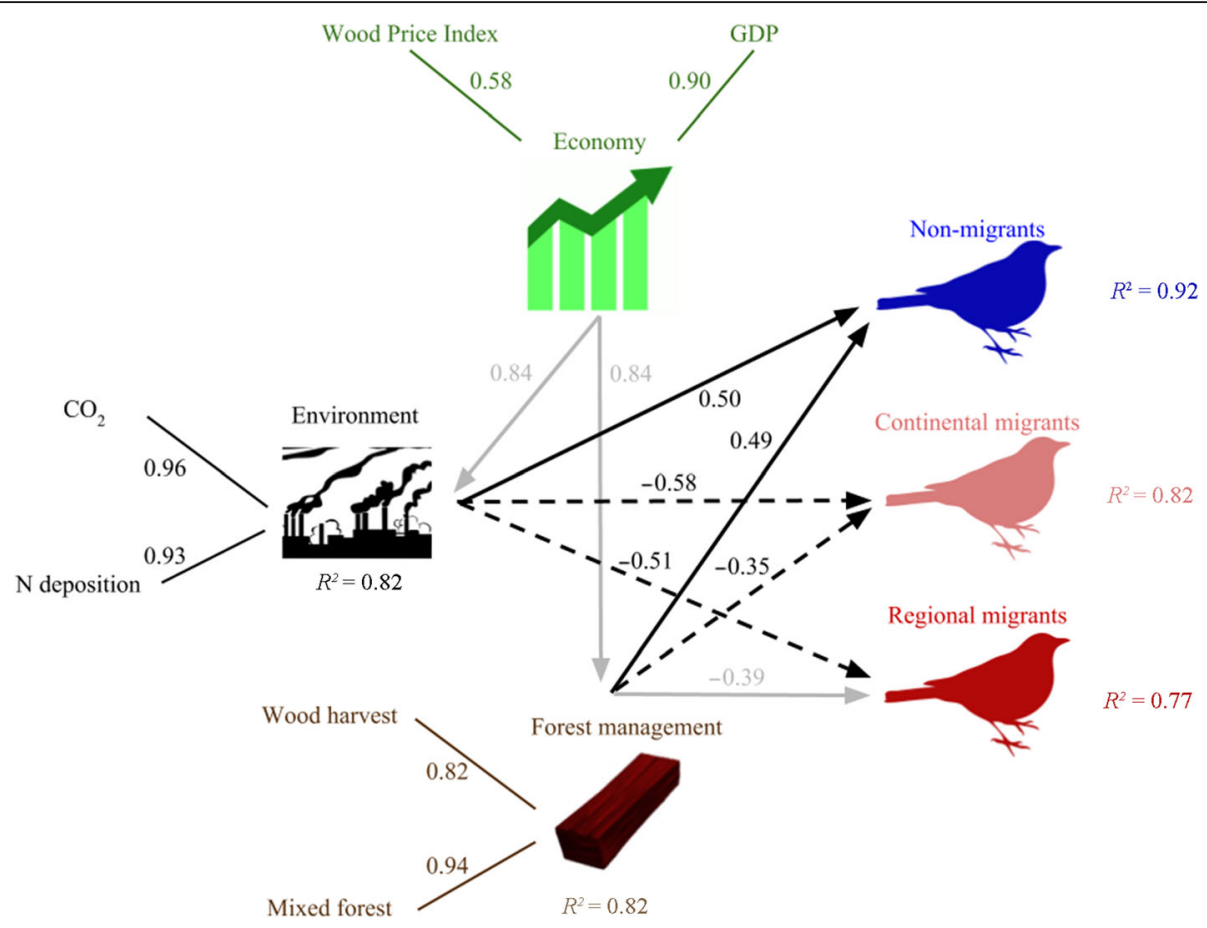

Fig. 4 Relationships between economic, environmental, and forest management effects on the abundance of non-migratory and migratory bird species in Central Europe from 1980 to 2014. Variables are grouped into the latent variables Economy, Environment, Forest Management, and for each group of birds (non-migrants, continental migrants, regional migrants). The direction and strength of relationships between the original variables and the respective latent variables are indicated by a solid line and standardized path coefficient. Significant path coefficients are represented as black arrows. Grey arrows indicate non-significant path coefficients. Note that 'non-migrants' correspond to those presented in Fig. 3. For bird genera see Methods Table 1

Christmas Bird Count (National Audubon Society 2018), we selected forest bird species that occupy similar niches to European forest bird species. The trend in NE-USA appears to be similar to that in central Europe, although the slope of population increase over time was lower than in Europe. The abundance of all but one bird species (Dryocopus pileatus) increased over time. The abundance of Certhia americana decreased between 1950 and 1970, but the population stabilized thereafter (Poulin et al. 2008) (Fig. 5).

\section{Discussion}

In this study we show that non-migratory forest birds have increased in population over the last several decades in Central Europe, while migratory birds have declined in abundance. We associate the response of the non-migratory birds with changes in the environment and in forest management. In contrast, migratory birds have constant or declining populations. At least some migrating species face increasing problems of coordinating migration due to climate change (Saino et al. 2011), but the complex reasons underlying the decline of migratory birds (see e.g. Vickery et al. 2014) were not addressed in this study.
There are a few exceptions to the general responses of migratory and non-migratory bird species. Among the European non-migratory forest specialists, Lesser Spotted Woodpeckers (Dendrocopos minor) declined from a very high population in the 1980 s, when they benefited from the widespread death of trees from acid rain (Flousek 1989). Bullfinches (Pyrrhula pyrrhula) have also declined, for reasons that are unknown (Siriwardena et al. 2001; Marquiss 2007), and have remained at a low level in parts of Europe. However, populations of both species appear to have stabilized over the past 5 to 10 years. There are also regionally migrating species that show increasing abundance, such as Stock Doves (Columba oenas), which might profit not only from the increasing abundance of Black Woodpeckers (Drycopus martius), because they use old nesting holes made by woodpecker (Kosiński et al. 2011) but also from increasing maize cultivation in agriculture, and Common Chiffchaffs (Phylloscopus collybita), which profit from an increase in the area of mixed forests (Gregory et al. 2007). Among the continentally migrating species, there is one species that has increased (Common Redstart, Phoenicurus phoenicurus; Fig. 2b). Common Redstarts breed in parks, gardens, sport fields, and other habitats where trees do not form a continuous canopy (Sedláček et al. 2004) and rely 


\section{Non-migratory bird species in eastern US}

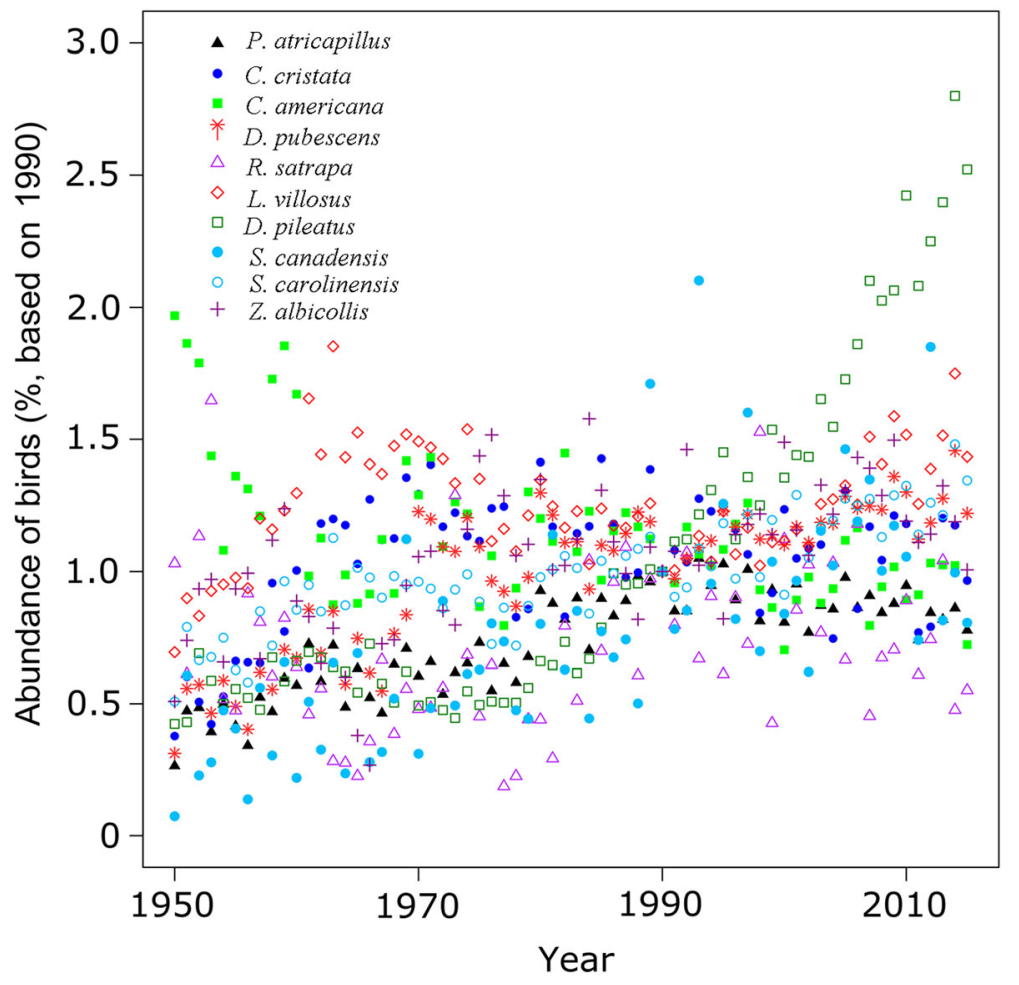

Fig. 5 Change in non-migratory bird populations of forest specialists in the 12 northeastern states of USA. The temporal trend is $y=0.0073 x+$ $0.749, r^{2}=0.1482$ ). Data are taken from National Audubon Society Christmas Bird Counts (National Audubon Society 2018). For species list and key, see methods Table 1

on areas with sparse vegetation for foraging (Martinez et al. 2010). Thus, the apparent increase may reflect a recovery from low numbers in the late twentieth century.

Our results appear to contradict the observation that severe declines in flying insects have cascading effects on bird populations (Hallmann et al. 2017). The study of Hallmann et al. (2017) is based on surveys of actively flying adult insects, not on larvae and insects that live in soil, on bark, or in tree canopies. In fact, it is possible that food supply did not decline in forests and thus forest birds may be limited rather by habitat availability than by food scarcity (Hansen et al. 1995; Wesolowski and TomiaJojć 1997; Martinez et al. 2010; Huang et al. 2015). For the United Kingdom it has been shown that insect abundance declined in open habitats only, and not in woodlands (Brooks et al. 2012). Moreover, there is evidence that invertebrate diversity is higher in forests with regular canopy openings and gaps (Ammer et al. 2017; Kunz 2017; Schall et al. 2018) than in forests with permanently closed canopies, and that bird species that are restricted to mature forests prefer open areas in the autumn after the end of the breeding season (Chandler et al. 2012). The situation is different on non-forest lands, where declining populations of non-forest bird species are related to the loss of insect biomass on arable lands (Hallmann et al. 2017; Kunz 2017), urbanization (Benítez-López et al. 2010; Ferenc et al. 2014), and could be further accentuated by habitat loss on arable land. Generally, we cannot exclude the possibility that wet summers may also result in an insect shortage in forests (Glutz von Blotzheim 2015), and climate change may change the situation in forests in the future. The situation on non-forest lands differs from forest lands, where most non-migratory forest birds show consistent positive trends across Central Europe (Burfield and Bommel 2004).

There are several possible reasons for the positive effect of modern climate change on non-migratory forest bird species, such as a longer growing season and less severe winters (Fu et al. 2015; Park et al. 2016). Modern forest management practices, which focus on maintaining higher standing wood volumes and increasing structural diversity, have a positive effect on numerous groups of vertebrates and invertebrates (Schall et al. 2018). For birds, the wood volumes and stand densities across Germany may even have reached a level that is too high, not allowing sufficient light on the forest floor (Kunz 2017). Non-migratory birds may also take 
advantage of declines in populations of migratory bird species through reduced competition, and migrating birds lose nesting sites, mainly nesting holes (Ahola et al. 2007). Moreover, resident forest birds could potentially increase population stability in urban areas and winter feeding (Robb et al. 2008). However, comparing the metropolitan area of Brussels, Belgium, with a nearby forest area in Wallonia shows that the suburban environment has no significant effect on forest bird populations (Weiserbs 2012). Notably, the observed positive effects of environment may not persist in light of expected larger changes in climate and climate variability over Europe towards the end of this century (IPCC 2013; Ram et al. 2017).

Forest management in Central Europe has shifted towards permanent canopy cover and selective harvests over the last three decades (Pukkala and von Gadow 2012). Although selective cutting can have negative effects on biodiversity (Paillet et al. 2010), it may be compensated for by an increase in the area of mixed-species forests (see Fig. 1) and increased stand volumes. The positive trends in forest bird populations over time are in contrast to previous observations, but these studies did not separate migratory and non-migratory species or account for land-use type (Leech and Crick 2007; Wade et al. 2013). Indeed, some forest specialist bird species, such as Tetrao urogallus (Capercaillie) and Tetrastes bonasia (Hazel Grouse), which are uncommon species and are not listed in the European Bird Observations, have experienced declines due to anthropogenic causes despite repeated efforts to restore populations through captive breeding and releasing. Trends for owls also appear to be variable. Small forest owls, such as Aegolius funereus and Glaucinium passerinum, have increased in populations with increased abundance of rodents, while some owls have profited from conservation efforts, such as Bubo bubo (Görner 2016). Grouses and owls are cryptic birds that are difficult to monitor because of their low detection probability (Wintle et al. 2005; Kéry and Schmid 2006; Zimmerman and Gutiérrez 2007; Hansen et al. 2011), and therefore they were not included in this study. All birds in our analysis are woodpeckers or passerines, which are smaller-bodied and have different evolutionary histories and ecologies, including higher detection probability.

It remains an open question whether conservation of forests can replace forest management. Setting aside forest areas from management in Central Europe is expected to result in the eventual monodominance of Fagus sylvatica. This phenomenon has been observed in Semenik National Park in Romania, where tree species diversity declined from a level similar to that found in managed forests in Germany to single species forests, possibly enhanced by interactions with deer populations
(Schulze 2017). Similar results were reported for nature reserves, where management was abandoned decades ago (Meyer 2005). Our findings are supported by observations of various groups of insects and plants (Schulze et al. 2016; Schall et al. 2018), which also show that forest management can help to increase biodiversity at the landscape scale. Together, these results highlight the inherent complexity of developing a flexible framework to conserve biodiversity (Glutz von Blotzheim 2001). Undoubtedly, there are many other factors that influence bird abundance at a variety of spatial and temporal scales, but the present study describes the most important drivers with which other variables are correlated at large spatial scales.

The question remains as to why migratory birds are in decline (see Fig. 4). Our model indicates a stronger negative effect of environment than of forest management on these species, but critically, the present model does not include changing conditions in the winter habitat or along the migration route (Vickery et al. 2014; Bairlein 2016). Further work is needed to explain the causal drivers underlying changes in the abundance of migratory species in central Europe. It is possible that including factors about environmental conditions along the migration route and in winter habitats could affect the correlations with the conditions in the summer habitats.

There may be multiple reasons for the different rates of increase in NE-USA and Europe of forest specialist bird populations, including differences in the absolute size of populations and the absolute area of habitat. We can exclude certain factors that could have affected bird populations in both regions, Europe and NE-USA. Forest area in both regions was relatively constant (0 to $5 \%$ changes in NE-USA; Sleeter et al. 2013; < 1\% changes in Central Europe; Forest Europe 2015). Several difficulties are associated with comparison of species and regions (Schipper et al. 2016). Nevertheless, the difference in the temporal response of bird abundance of NE-USA and European may be interpreted as a result of less intensive timber harvesting in hardwood forests (USDA Forest Service 2018; Thünen-Institut 2012). The increase in bird abundance in the NE-USA has a lower slope at a much lower level of wood removal compared to Central Europe (USDA Forest Service 2018 ). The average slope of bird abundance per year across 12 states in NE-USA was $0.87 \%$, compared to an average wood extraction rate of $0.72 \mathrm{~m}^{3} \cdot \mathrm{yr}^{-1}{ }^{-1} \mathrm{ha}^{-1}$ (s.d. $0.5 \mathrm{~m}^{3} \cdot \mathrm{yr}^{-1} \cdot \mathrm{ha}^{-1}$ ). The average slope of bird abundance per year in central Europe was 1.45\% (see Fig. 2 for Europe and Fig. 4 for USA) compared to an average wood extraction rate of $6.3 \mathrm{~m}^{3} \cdot \mathrm{yr}^{-}$ ${ }^{1} \cdot \mathrm{ha}^{-1}$ (s.d. $\left.1.3 \mathrm{~m}^{3} \cdot \mathrm{yr}^{-1} \cdot \mathrm{ha}^{-1}\right)$. The differences in wood extraction rates are associated with changes in forest structure and tree diversity. Due to a lack of further 
data, wood harvest is taken as only one of many factors that have changed in managed forests. This may indicate that forest management has had a positive impact on the trajectory of bird populations. In the eastern USA, Sheehan et al. (2014) manipulated forest management intensity to examine its impacts on the population densities of the Cerulean Warbler, Setophaga cerulea. They found that they peaked in forests with intermediate levels of residual basal area, yet late successional species responded negatively to increasing forest management intensity. Compared to forests in NE-USA, or at least those studied in Sheehan et al. (2014), European managed forests typically reach much higher basal areas and higher small-scale diversity in age classes and structure. Thus, late successional bird species in Europe likely had sufficient access to nesting and feeding sites to maintain their abundance levels.

\section{Conclusions}

In conclusion, environmental change and forest management were significantly positively related to biodiversity, as measured by the abundance of native forest bird specialists. The main environmental changes are most likely a prolonged growing season and milder temperatures in winter and less air pollution. Environment conditions in Europe also have been changed indirectly by forest management via an increase in the area of mixed-species forests and by increasing volumes of life and dead wood and of structural diversity. Studies of rare and endangered plant species (Schulze et al. 2016), fungi and other microorganisms (Felsmann et al. 2015), reptiles (Jaggi and Baur 1999; Nöllert 2004; Serfling and Serfling 2017), and on 15 taxonomic groups of vertebrates and invertebrates in managed even-aged and uneven-aged and unmanaged beech forests in central Germany (Schall et al. 2018) also suggest that forest management can have positive effects on biodiversity by creating more heterogeneous habitats (Hansen et al. 1995; Doyon et al. 2005). The data from the NE-USA show similar trends. Based on these findings from two large temperate regions, we conclude that there is evidence that, in addition to large-scale environmental changes, sustainable forest management can have long-lasting and even positive effects on biodiversity. Ultimately, no single practice of forest management can provide suitable habitat conditions for the conservation of all forest bird species (King and DeGraaf 2000; Vanderwel et al. 2007; Haulton 2008). This finding should not preclude the availability of a diversity of strategies to decision makers to create landscape mosaics that enhance or stabilize biodiversity within and among habitats and land-uses, which is particularly relevant because continental and regional migratory birds showed different temporal trends in abundance than non-migratory forest birds. Thus, in a world of biodiversity change, the potential of sustainable forest management to maintaining biodiversity should be revisited.

\section{Abbreviations}

PECBMS: Pan European Common Bird Monitoring Scheme

\section{Acknowledgements}

NE gratefully acknowledges the support of the German Centre for integrative Biodiversity Research (iDiv) Halle-Jena-Leipzig funded by the German Research Foundation (FZT 118). JR was supported by Charles University, Praque (project no. PRIMUS/17/SCI/16). We acknowledge the helpful discussions concerning bird-life in Europe with Prof. Dr. Peter Berthold and Dr. F Bairlein, and the permission to use the Wallonian bird observation data by JY Paquet. We acknowledge the help of Petra Sorglos, forest owner association, for help finding the time series of wood prices, and Dirk Günther, Umweltbundesamt, for the time series of N-deposition. Christmas Bird Count data are provided by the National Audubon Society and through the generous efforts of Bird Studies Canada and countless volunteers across the western hemisphere (www.audubon.org, www.christmasbirdcount.org). We want to thank Annett Börner (www.dn.com.au/annett-boerner.html) for the art work.

Funding

JR: German Research Foundation (FZT 118), Charles University (Primus/17/ $\mathrm{SCl} / 16)$.

\section{Availability of data and materials}

The datasets used and/or analyzed during the current study are cited or are available from the corresponding author on reasonable request.

\section{Authors' contributions}

EDS developed the idea and wrote the first draft. DC developed the path analyses. AD edited the paper and obtained the US bird and forest data. MG developed the time series graphs. NE edited the paper and gave zoological advice. JR supplied the Czech bird data. AW supplied the Belgian bird data. FK and PH supplied the German forest data. CA and PS gave advice on forest management. All authors read and approved the final manuscript.

\section{Ethics approval and consent to participate}

Not applicable.

\section{Consent for publication}

Not applicable.

\section{Competing interests}

The authors declare that they have no competing interests.

\section{Author details}

${ }^{1}$ Max Planck Institute for Biogeochemistry, PO Box 100164, 07701 Jena, Germany. ${ }^{2}$ Biodiversity, Macroecology and Biogeography, Faculty of forest Science and Forest Ecology, University Göttingen, Buesgenweg 1, 37077 Göttingen, Germany. ${ }^{3}$ Institute of Environmental Studies, Faculty of Science, Charles University, Prague, Benatska 2, 12801 Praha 2, Czech Republic. ${ }^{4}$ Thünen-Institute for Forest Ecosystems, Alfred-Möller Str 1, 16225 Eberswalde, Germany. ${ }^{5}$ Aves-Natagora, Départment Etudes, 1 Traverse des Muses, 5000 Namur, Belgium. ${ }^{6}$ Silviculture and Forest Ecology of the temperate Zones, University of Göttingen, Büsgenweg 1, 37077 Göttingen, Germany. ${ }^{7}$ German Centre for Integrative Biodiversity Research (iDiv), and Leipzig University, Institute of Biology, Deutscher Platz 5e, 04103 Leipzig, Germany.

Received: 9 October 2018 Accepted: 4 January 2019

Published online: 29 January 2019

\section{References}

Ahola MP, Laaksonen T, Eeva T, Lehikoinen E (2007) Climate change can alter competitive relationships between resident and migratory birds. J An Ecol 76:1045-1052

Ammer C, Schall P, Gossner MM, Heinrichs S, Boch S, Prati D, Jung $K$ Baumgartner V, Blaser S, Böhm S, Buscot F, Daniel R, Goldmann K, Kaiser K, Kahl T, Lange M, Müller J, Overmann J, Renner SC, Schulze ED, Sikorski J, 
Tschapka M, Türke M, Weisser WW, Wemheuer B, Wubet T, Fischer M (2017) Waldbewirtschaftung und Biodiversität: Vielfalt ist gefragt. Allgemeine Forstzeitschrift/Der Wald 72:20-25

Armstrong A (2017) Biodiversity. Nature 546:47

Bairlein F (2016) Migratory birds under threat. Science 354:547-548

Bakermans MH, Rodewald AD (2009) Think globally, manage locally: the importance of steady-state forest features for a declining songbird. Forest Ecol Manag 258:224-232

Benítez-López A, Alkemade R, Verweij PA (2010) The impacts of roads and other infrastructure on mammal and bird populations: a meta-analysis. Biolog Conserv 143:1307-1316

Berndt R, Winkel W (1979) Zur populationsentwicklung von Blaumeise (Parus caeruleus), Kleiber (Sitta europaea), Gartenrotschwanz (Phoenicurus phoenicurus) und Wendehals (Jynx torquilla) in mitteleuropäischen Untersuchungsgebieten von 1927 bis 1978. Die Vogelwelt 100:55-69

BMU (2007) Nationale Strategie zur Biologischen Vielfalt. Bundesministerium für Umwelt. Naturschutz und Reaktorsicherheit, Bonn

Braun-Blanquet J (1964) Pflanzensoziologie, 2nd edn. Fischer Verlag, Stuttgart Brooks DR, Bater JE, Clark SJ, Monteith DT, Andrews C, Corbett SJ, Beaumont DA, Chapman JW (2012) Large carabid beetle declines in a United Kingdom monitoring network increases for a widespread loss in insect biodiversity. J Appl Ecol 49:1009-1019

Brumme R, Khanna PK (2009) Functioning and management of European beech ecosystems. Springer, Berlin

Bundesamt für Naturschutz (2015) Artenschutz-Report 2015: Tiere und Pflanzen in Deutschland. Bundesamt für Naturschutz, Bonn

Burfield I, van Bommel F (2004) Birds in Europe: population estimates, trends and conservation status. Birdlife International, Cambridge

Cardinale BJ, Duffy JE, Gonzalez A, Hooper DU, Perrings C, Venail P, Narwani A, Mace GM, Tilman D, Wardle DA (2012) Biodiversity loss and its impact on humanity. Nature 486:59-67

Chandler CC, King DI, Chandler RB (2012) Do mature forest birds prefer earlysuccessional habitat during the post-fledging period? Forest Ecol Manag 264:1-9

Core Team R (2018) R: A Language and Environment for Statistical Computing. R Foundation for Statistical Computing, Vienna https://www.R-project.org/. Accessed 10 Sept 2018

Donald P, Green R, Heath M (2001) Agricultural intensification and the collapse of Europe's farmland bird populations. Proc R Soc London B Biol Sci 268:25-29

Doyon F, Gagnon D, Giroux JF (2005) Effects of strip and single-tree selection cutting on birds and their habitat in a southwestern Quebec northern hardwood forest. Forest Ecol Manag 209:101-116

Drobyshev I, Niklasson M, Mazerolle MJ, Bergeron Y (2014) Reconstruction of a 253-year long mast record of European beech reveals its association with large scale temperature variability and no long-term trend in mast frequencies. Agr Forest Meteorol 192:9-17

Du E, de Vries W, Galloway JN, Hu X, Fang J (2014) Changes in wet nitrogen deposition in the United States between 1985 and 2012. Environm Res Lett 9:095004

European Bird Census Council (2018) Pan-European Common Bird Monitoring Scheme. http://www.ebcc.info/pan-european-common-bird-monitoringscheme-pecbms/. Accessed 10 Sept 2018

European Commission (2015) Natura 2000 and Forests. Part I-II. Office for Official Publications of the European Communities, Luxembourg

European Environment Agency (1998) Europe's Environment. The Second Assessment. Part 4. European Environment Agency, Copenhagen

Felsmann K, Baudis M, Gimbel K, Kayler ZE, Ellerbrock R, Bruehlheide H, Bruckhoff J, Welk E, Puhlmann H, Weiler M (2015) Soil bacterial community structure responses to precipitation reduction and forest management in forest ecosystems across Germany. PloS One 10:e0122539

Ferenc M, Sedláček O, Fuchs R, Dinetti M, Fraissinet M, Storch D (2014) Are cities different? Patterns of species richness and beta diversity of urban bird communities and regional species assemblages in Europe. Global Ecol Biogeogr 23:479-489

Flousek J (1989) Impacts of industrial emissions on bird populations breeding in mountain spruce forests in central Europe. Ann Zoolog Fenn 26:255-263

Forest Europe (2015) State of Europe's Forests 2015, 4th edn. Food \& Agriculture Organisation of the United Nations, Madrid

Fu YH, Zhao H, Piao S, Peaucelle M, Peng S, Zhou G, Ciais P, Huang M, Menzel A, Peñuelas J (2015) Declining global warming effects on the phenology of spring leaf unfolding. Nature 526:104-107

Glutz von Blotzheim UN (2001) Sturmwurfflächen - werden die heranwachsenden Wälder auch optimale Lebensräume für Pflanzen und Tiere? Ornithol. Beob 98:81-112
Glutz von Blotzheim UN (2015) Finden Gartenrotschwänze Phoenicurus phoenicurus noch überall genügend Insekten, um erfolgreich Junge aufzuziehen. Ornith Beobacht 112:51-56

Görner M (2016) Zur Ökologie des Uhus (Bubo bubo) in Thüringen - eine Lanzeitstudie. Artenschutzbericht 8:1-320

Gregory RD, Vorisek P, Van Strien A, Gmelig Meyling AW, Jiguet F, Fornasari L Reif J, Chylarecki P, Burfield IJ (2007) Population trends of widespread woodland birds in Europe. Ibis 149:78-97

Hallmann CA, Sorg M, Jongejans E, Siepel H, Hofland N, SchwanH SW, Müller A Sumser H, Hörren T (2017) More than 75 percent decline over 27 years in total flying insect biomass in protected areas. PloS One 12:e0185809

Hansen AJ, McComb WC, Vega R, Raphael MG, Hunter M (1995) Bird habitat relationships in natural and managed forests in the west Cascades of Oregon. Ecolog Applic 5:555-569

Hansen CP, Millspaugh JJ, Rumble MA (2011) Occupancy modeling of ruffed grouse in the Black Hills National Forest. J Wildlife Manag 75:71-77

Haulton S (2008) Effects of silvicultural practices on bird communities in deciduous forests of eastern and central North America: A Literature Review with Recommendations for Management. Indiana Department of Natural Resources. http://www.indiana.gov/dnr/forestry/files/fo-mamangedForestBirReview.pdf

Hines J, Eisenhauer N, Drake BG (2015) Inter-annual changes in detritus-based food chains can enhance plant growth response to elevated atmospheric $\mathrm{CO}_{2}$. Global Chang Biol 21:4642-4650

Houghton RA, Hackler JL, Lawrence KT (1999) The US carbon budget: contributions from land-use change. Science 285:574-578

Huang Y, Zhao Y, Li S, von Gadow K (2015) The effects of habitat area, vegetation structure and insect richness on breeding bird populations in Beijing urban parks. Urban Forest Urban Green 14:1027-1039

Inger R, Gregory R, Duffy JP, Stott I, Voříšek P, Gaston KJ (2015) Common European birds are declining rapidly while less abundant species' numbers are rising. Ecol Lett 18:28-36

IPCC (2013) Climate Change 2013. The Physical Science Basis. Cambridge University Press, Cambridge

Jaggi C, Baur B (1999) Overgrowing forest as a possible cause for the local extinction of Vipera aspis in the northern Swiss Jura mountains. AmphibiaReptilia 20:25-34

Keenan TF, Gray J, Friedl MA, Toomey M, Bohrer G, Hollinger DY, Munger JW, O'Keefe J, Schmid HP, Wing IS (2014) Net carbon uptake has increased through warming-induced changes in temperate forest phenology. Nat Clim Change 4:598-604

Kéry M, Schmid H (2006) Estimating species richness: calibrating a large avian monitoring programme. J Appl Ecol 43:101-110

King DI, DeGraaf RM (2000) Bird species diversity and nesting success in mature, clearcut and shelterwood forest in northern New Hampshire, USA. Forest Ecol Manag 129:227-235

Kosiński Z, Bilińska E, DerezińskiJ KM (2011) Nest-sites used by Stock Doves Columba oenas: what determines their occupancy? Acta Ornithol 46:155-163

Kunz W (2017) Artenschutz durch Habitatmanagement. Der Mythos von der unberührten Natur. Wiley-Vhc Verlag, Weinheim

Küster H (2003) Geschichte des Waldes: von der Urzeit bis zur Gegenwart. CH Beck, München

Le Quéré C, Andrew RM, Canadell JG, Sitch S, Korsbakken Jl, Peters GP, Manning AC, Boden AT, Tans PP, Houghton RA, Keeling RF, Alin S, Andrews OD, Anthoni P, Barbero L, Bopp L, Chevallier F, Chini LP, Ciais P, Currie K, Delire C, Doney SC, Friedlingstein P, Gkritzalis T, Harris I, Hauck J, Haverd V, Hoppema M, Klein Goldewijk K, Jain AK, Kato E, Körtzinger A, Landschützer P, Lefèvre N, Lenton A, Lienert S, Lombardozzi D, Melton JR, Metzl N, Millero F, PMS M, Munro DR, JEMS N, Nakaoka SI, O'Brien K, Olsen A, Omar AM, Ono T, Pierrot D, Poulter B, Rödenbeck C, Salisbury J, Schuster U, Schwinger J, Séférian R, Skjelvan I, Stocker BD, Sutton AJ, Takahashi T, Tian H, Tilbrook B, van der Laan-Luijkx IT, van der Werf GR, Viovy N, Walker AP, Wiltshire AJ, Zaehle S (2016) Global carbon budget 2016. Earth Syst Sci Data 8:605-649

Leech D, Crick H (2007) Influence of climate change on the abundance, distribution and phenology of woodland bird species in temperate regions. Ibis 149:128-145

Marquiss M (2007) Seasonal pattern in hawk predation on Common Bullfinches Pyrrhula pyrrhula: evidence of an interaction with habitat affecting food availability. Bird Study 54:1-11

Martinez N, Jenni L, Wyss E, Zbinden N (2010) Habitat structure versus food abundance: the importance of sparse vegetation for the common redstart Phoenicurus phoenicurus. J Ornithol 151:297-307 
Meyer P (2005) Network of Strict Forest Reserves as reference system for close to nature forestry in Lower Saxony, Germany. Forest Snow Landscape Res 79: 33-44

National Audubon Society (2018) The Christmas Bird Count Historical Results. http://netapp.audubon.org/CBCObservation/Historical/ResultsBySpecies. aspx?1. Accessed 10 Sept 2018

Nöllert A (2004) Verbreitung, Lebensraum und Bestandessituation der Kreuzotter Vipera berus berus (Linnaeus, 1758) im Freistaat Thüringen. Mertensiella 15:52-90

Organisation for Economic Cooperation and Development (2008) Aggregate National Accounts, SNA 2008. https://www.oecd-ilibrary.org/economics/data/ aggregate-national-accounts-sna-2008_na-ana08-data-en. Accessed 10 Sept 2018

Paillet Y, Bergès L, Hjältén J, Ódor P, Avon C, Bernhardt-Römermann M, Bijlsma RJ, De Bruyn L, Fuhr M, Grandin U (2010) Biodiversity differences between managed and unmanaged forests: meta-analysis of species richness in Europe. Conserv Biol 24:101-112

Park T, Ganguly S, Tømmervik H, Euskirchen ES, Høgda KA, Karlsen SR, Brovkin V, Nemani RR, Myneni RB (2016) Changes in growing season duration and productivity of northern vegetation inferred from long-term remote sensing data. Environm Res Lett 11:084001

Parmesan C, Yohe G (2003) A globally coherent fingerprint of climate change impacts across natural systems. Nature 421:37-42

Pollock L, Thuiller W, Jetz W (2017) Large conservation gains possible for global biodiversity facets. Nature 546:141-144

Poulin JF, Villard MA, Edman M, Goulet JP, Eriksson MA (2008) Thresholds in nesting habitat requirements of an old forest specialist, the Brown Creeper (Certhia americana), as conservation targets. Biologic Conserv 141:1129-1137

Pukkala T, von Gadow K (2012) Continuous cover forestry. Book Series: Managing Forest Ecosystems 24. Springer, Berlin

Ram D, Axelsson LA, Green M, Smith HG, Lindström A (2017) What drives current population trends in forest birds-forest quantity, quality or climate? A largescale analysis from northern Europe. Forest Ecol Manag 385:177-188

Reif J, Hanzelka J (2016) Grassland winners and arable land losers: The effects of post-totalitarian land use changes on long-term population trends of farmland birds. Agric Ecosyst Environm 232:208-217

Reif J, Storch D, Voříšek P, Štastný K, Bejček V (2008) Bird-habitat associations predict population trends in central European forest and farmland birds. Biodivers Conserv 17:3307-3319

Reif J, Voříšek P, Štastný K, Bejček V, Petr J (2007) Population increase of forest birds in the Czech Republic between 1982 and 2003. Bird Study 54:248-255

Robb GN, McDonald RA, Chamberlain DE, Bearhop S (2008) Food for thought: supplementary feeding as a driver of ecological change in avian populations. Front Ecol the Environ 6:476-484

Saino N, Ambrosini R, Rubolini D, von Hardenberg J, Provenzale A, Hüppop K, Hüppop O, Lehikoinen A, Lehikoinen E, Rainio K (2011) Climate warming, ecological mismatch at arrival and population decline in migratory birds. Proc R Soc London B Biol Sci 278:835-842

Sanchez G, Trinchera L, Russolillo G (2013) plspm: Tools for partial least squares path modeling (PLS-PM). R package version 0.4

San-Miguel-Ayanz J, de Rigo D, Caudullo G, Durrant TH, Mauri A, Tinner W, Ballian D, Beck P, Birks H, Eaton E (2016) European Atlas of Forest Tree Species. Publication Office of the European Union, Luxembourg

Schall P, Gossner MM, Heinrichs S, Fischer M, Boch S, Prati D, Jung K, Baumgartner V, Blaser S, Böhm S (2018) The impact of even-aged and uneven-aged forest management on regional biodiversity of multiple taxa in European beech forests. J Appl Ecol 55:267-278

Schipper AM, Belmaker J, de Miranda MD, Navarro LM, Böhning-Gaese K, Costello MJ, Dornelas M, Foppen R, Hortal J, Huijbregts MA (2016) Contrasting changes in the abundance and diversity of North American bird assemblages from 1971 to 2010. Global Change Biol 22:3948-3959

Schulze ED (2017) Effects of forest management on biodiversity in temperate deciduous forests: an overview based on Central European beech forests. $J$ Nature Conserv 43:213-226

Schulze ED, Bazzaz F, Nadelhoffer K, Koike T, Takatsuki S (1996) Biodiversity and ecosystem function of temperate deciduous broad-leaved forests. Scope 55:71-98

Schulze ED, Boch S, Müller J, Levick S, Schumacher J (2016) Seltene und gefährdete Pflanzen wachsen im Laubwald überall. AFZ-DerWald 13:35-38

Sedláček O, Fuchs R, Exnerová A (2004) Redstart Phoenicurus phoenicurus and black redstart $P$. ochruros in a mosaic urban environment: neighbours or rivals? J Av. Biol 35:336-343
Serfling C, Serfling F (2017) Untersuchungen zur Bestandessituation der Kreuzotter Vipera berus im Thüringer Wald und seinen Randbereichen im Jahr 2015. Landschaftspflege und Naturschutz in Thüringen 54:3-9

Sheehan J, Wood PB, Buehler DA, Keyser PD, Larkin JL, Rodewald AD, Wigley TB, Boves TJ, George GA, Bakermans MH (2014) Avian response to timber harvesting applied experimentally to manage Cerulean Warbler breeding populations. Forest Ecol Manag 321:5-18

Siriwardena GM, Freeman SN, Crick HQ (2001) The decline of the Bullfinch Pyrrhula pyrrhula in Britain: is the mechanism known? Acta Ornithol 36:143-152

Sleeter BM, Sohl TL, Loveland TR, Auch TR, Acevedo W, Drummond MA, Sayler $\mathrm{KL}$, Stehman SV (2013) Land-cover change in the conterminous United States from 1973 to 2000. Global Environm Change 23:733-748

Steinsiek P (2016) Forstwirtschaft im "Dritten Reich". ProWald Juli 2016:4-7

Thünen-Institut (2012) Dritte Bundeswaldinventur - Ergebnisdatenbank. https:// bwi.info/start.aspx. Accessed 10 Sept 2018

Thünen-Institut (2016) International Co-operative Programme on Assessment and Monitoring of Air Pollution Effects on Forests. http://icp-forests.net/. Accessed 10 Sept 2018

Umweltbundesamt (2015) Monitoringbericht 2015 zur Deutschen Anpassungsstrategie an den Klimawandel: Bericht der Interministeriellen Arbeitsgruppe Anpassungsstrategie der Bundesregierung. Umweltbundesamt, Dessau-Roßlau

USDA Forest Service (2018). Design and Analysis Toolkit for Inventory \& Monitoring (DATIM). Version 9.0.0. https://apps.fs.usda.gov/DATIM/Default. aspx. Accessed 10 Sept 2018

Vanderwel MC, Malcolm JR, Mills SC (2007) A meta-analysis of bird responses to uniform partial harvesting across North America. Conserv Biol 21:1230-1240

Vicca S, Luyssaert S, Penuelas J, Campioli M, Chapin IIIF, Ciais P, Heinemeyer A, Högberg P, Kutsch W, Law BE, Malhi Y, Papale D, Piao SL, Reichstein M, Schulze ED, Janssens IA (2012) Fertile forests produce biomass more efficiently. Ecol Lett 15:520-526

Vickery JA, Ewing SR, Smith KW, Pain DJ, Bairlein F, Škorpilová J, Gregory RD (2014) The decline of Afro-Palaearctic migrants and an assessment of potential causes. Ibis 156:1-22

Voigt W, Perner J, Hefin Jones T (2007) Using functional groups to investigate community response to environmental changes: two grassland case studies. Global Change Biol 13:1710-1721

Wade AS, Barov B, Burfield IJ, Gregory RD, Norris K, Butler SJ (2013) Quantifying the detrimental impacts of land-use and management change on European forest bird populations. PloS One 8:e64552

Weimar H (2016) Holzbilanzen 2013 bis 2015 für die Bundesrepublik Deutschland. Thünen Working Paper 57:13

Weiserbs A (2012) Vingt ans de suivi de l'avifaune commune á Bruxelles. Aves 9: $13-21$

Wesolowski T, TomiaJojć L (1997) Breeding bird dynamics in a primaeval temperate forest: long-term trends in Biatowieza National Park (Poland). Ecography 20:432-453

Winkel W (2002) Sind Singvögel Anzeiger von Umwelt-und Klimaveränderungen? Langzeittrends bei Meisen und anderen Kleinhöhlenbrütern im Braunschweiger Raum. Milvus Braunschweig 21:1-12

Wintle BA, Kavanagh RP, McCarthy M, Burgman MA (2005) Estimating and dealing with detectability in occupancy surveys for forest owls and arboreal marsupials. J Wildlife Manag 69:905-917

Zimmerman GS, Gutiérrez R (2007) The influence of ecological factors on detecting drumming ruffed grouse. J Wildlife Manag 71:1765-1772

Zvelebil M (2001) The agricultural transition and the origins of Neolithic society in Europe. Documenta Praehistorica 28:1-26 